\title{
Original Article \\ Space, place and temporality in stem cell and cancer tissue banking: Mediating between patient-donors and biomedical research
}

\author{
Neil Stephens \\ ESRC Centre for the Economic and Social Aspects of Genomics (Cesagen), Cardiff \\ University School of Social Sciences, 6 Museum Place, Cardiff, CF10 3BG, UK. \\ E-mail: StephensN@Cardiff.ac.uk
}

\begin{abstract}
This article reports on two qualitative studies of tissue banks in the United Kingdom: the onCore UK Cancer Tissue Bank and the UK Stem Cell Bank. I use the language of Waldby and Mitchell's tissue economies to interrogate the shared ground between the two institutions as collators, moral guardians and distributors of human tissue. The article articulates the key ontological and ethical differences between cancer tissue taken directly from patients and embryonic stem cell material taken from 'spare' IVF embryos donated by couples undergoing treatment. In this context, a key focus of the article is the spatial and temporal formations both constraining and produced by each bank to demonstrate the ways in which both institutions are engaged in bringing stable modes of exchange to socially complex human tissue, to both control temporal multiplicity and tame geographical spread. I take seriously the spaces and places of each bank, and the movement and flows of tissue through them to demonstrate how tissue banks operate as 'moral refineries' supplying healthcare research.

Social Theory \& Health (2012) 10, 245-264. doi:10.1057/sth.2012.5;

published online 4 July 2012
\end{abstract}

Keywords: cancer; stem cells; human tissue; banking; space; temporality

\section{Introduction}

Tissue collections have long existed at the interface of patient-donors and biomedical research. ${ }^{1}$ In the United Kingdom, the last decade has seen an increase in the formalisation of tissue collections into tissue banks: centralised holdings of ethically sourced human tissue for research purposes. A key reason

(C) 2012 Macmillan Publishers Ltd. 1477-8211 Social Theory \& Health Vol. 10, 3, 245-264 www.palgrave-journals.com/sth/ 
for this in the UK context is the high-profile condemnation of the retention of children's organs without parental permission by Alder Hey Children's Hospital and Bristol Royal Infirmary around the millennium. This resulted in the establishment of a regulatory body in 2005 - the Human Tissue Authority - that monitors and licences all holdings of human tissue in England and Wales. Another driving force towards the foundation of biobanks is the promise of scientific development, with large-scale genomic studies requiring institutions like UK Biobank (Tutton, 2007), and the storage of cell lines for tissue engineering creating bodies like the UK Stem Cell Bank. Recent EU initiatives, including the recently launched AXLR8, will also strengthen this move as governments and companies such as AstraZeneca, Procter \& Gamble and Unilever increase their calls for human tissue-based alternatives to animal experiments in drug toxicology (Gray, 2010; Harrington and Stephens, 2010). In this context, tissue banks have an increasingly important role as mediating actors between patient-donors and researchers looking to produce medicinal products and biomedical knowledge.

This article reports on two studies of tissue banks in the United Kingdom: the onCore UK Cancer Tissue Bank and the UK Stem Cell Bank. A key focus of the article is the spatial and temporal formations both constraining and produced by each bank to demonstrate the ways in which both institutions are engaged in bringing stable modes of exchange to socially complex human tissue, to both control temporal multiplicity and tame geographical spread. I take seriously the spaces and places of each bank, and the movement and flows of tissue through them (Eriksson et al, 2008) to demonstrate how tissue banks operate as 'moral refineries' supplying healthcare research (Stephens et al, 2008a). Explicitly, the article aims to address the following question: In these two detailed empirical studies, how do spatial and temporal aspects challenge and help materialise each bank's institutional imaginary?

I take my lead for theorising the spatial aspects of biobanking from Gieryn $(1999,2002)$ and Thrift $(2006)$. Gieryn's work on the production and maintenance of rhetorical boundaries between science and non-science is familiar and useful in this context. However, I am also keen to emphasise Gieryn's reflections on boundaries mapped across physical spaces - buildings in particular - that frame, or are framed by, the imaginaries of those who use, build and occupy them. To this end, I will re-interpret Thrift's work on Performative Architecture in the context of physical and organisational biobanking structures evident in my empirical work and the complex temporal contexts around and within them.

My articulation and analysis of these temporal complexities will be informed by the work of Adam $(1990,1998,2004)$ and her conceptualisation of timescapes. Her work provides a framework for thinking through the experience and impact of time on individuals, contexts and things - their timescape - through eight related components: time frame (seconds, days, eras), temporality (process, 
irreversibility), tempo (pace, intensity), time point (moment, instant), time patterns (rhythmicity, cyclicality), time sequence (series), time extensions (duration, continuity) and time past/present/future. Each of these will be used in the article to work through the empirical case studies, making the temporal explicit and demonstrating the relatedness of time and space in social organisation.

Institutional Imaginary is a term used to reflect the communally held vision of the future that frames the activities and aspirations within each individual institution, inherently an issue of time pasts, presents and futures. The concept of imaginaries has been used by Jasanoff and Kim (2009) in the context of nation states' science policies, Kelty (2005) in the context of computer hackers, Gross (2004) in the context of refugees and healthcare professionals, and Taylor (2004) in the context of Western modernity. All reflect upon the performative nature of collective visions in structuring current practice. Scientific institutions, such as the banks discussed here, are framed by a nation state's science policy, and institutional imaginaries are in turn framed in terms of, and operate in dialogue with, broader national imaginaries. These institutional and national imaginaries can stand in relative harmony or in tension, as reflected in the social and historical contexts of the organisations involved.

Jasanoff and Kim (2005), in contrast to Taylor (2004), develop the key concept of 'socio-technical imaginaries' that draws together future-orientated vision with techno scientific and institutional capacity (Rommetveit, 2011). Although Taylor's 'social imaginaries' relate to the autonomous individual, consideration of the socio-technical allows us to conceptualise the inter-relatedness of individuals, institutions, knowledge sources and technical practices. It is clear that the institutional imaginaries discussed here are inherently sociotechnical, being embedded within practical and physical environments. My focus on spatiality and temporality works to make the socio-technical explicit. However, like Pickersgill (2011), this article explores socio-technical imaginaries as operated in the micro-social processes and institutions of tissue banking.

Although the two types of human material held in each bank - human embryonic stem cells (hESC) ${ }^{2}$ and cancer tissue - are quite different in their properties and potentials, both banks exist to maximise the healthcare productivity of their tissue in socially responsible ways. As such, they operate as part of what Waldby and Mitchell (2006, p. 31) term the 'tissue economy', 'a system for maximising [tissue's] productivity, through strategies of circulation, leverage, diversification, and recuperation'. Indeed, Waldby and Mitchell in part develop the concept in relation to the UK Stem Cell Bank, using Callon's (1998) language of entanglement and disentanglement to describe the symbolic work of the bank to move hESC material from patient-orientated networks of kinship to research-orientated networks of international exchange. I develop Waldby and Mitchell's theoretical analysis further by bringing it to empirical experience. 
This article is based on 3 years of ethnographic fieldwork at the UK Stem Cell Bank (2005-2008) and sustained contact since. I complement this with 2 years of interview and observational data collection at onCore UK (2008-2010). ${ }^{3}$ This provides empirical scrutiny on the practical issues of spatial and temporal framing at the banks.

During these data collection periods, both banks experienced periods of change. The most dramatic change affected onCore UK, who in May 2009 received directions from their Board of Trustees to cease biobanking activity and instead adopt an advocacy and advisory role for the UK cancer biobanking community. Then in October 2010, the Board of Trustees made another announcement stating that, while a sub-section of the advisory activities of onCore UK should continue, they should be conducted by other organisations under the National Cancer Research Institute umbrella. This transition was completed by February 2011, when onCore UK ceased to exist. Subsequently, the data collected cover a period of active biobanking, crisis, dismantling of their biobanking infrastructure, re-structuring in a new advisory capacity and then again dis-mantling this advisory infrastructure. In this article, the comparison between the UK Stem Cell Bank and onCore UK will focus primarily on the early period when onCore UK remained actively biobanking. I reflect on how the subsequent period of crisis relates to the discussion developed in the article in the closing section.

The article is divided into six sections. Following this Introduction, I describe the institutional imaginaries of the stem cell and cancer tissue banks. I make explicit the ethical and ontological specifics of the two tissue types that frame each bank differently. The next section details each bank's financial and institutional context. The section after that discusses the substantive theoretical issue of banks as spaces and places, detailing how the conceptual and physical geography of each positions them as 'moral refineries'. The penultimate section engages with the related issue of the complex temporalities of hESC and cancer tissue entangled in the values of patienthood, and how the banks function to re-frame this complexity into a form suitable for exchange in the tissue economy. The final discussion section considers how the theoretical drivers of the article relate to the empirical reality of onCore UK's closure. In totality, the article's focus is a theoretical analysis of the work performed by tissue banks as mediators between donor-patients and scientists to provide ethically legitimate and logistically stable supplies of morally and temporally complex human tissue for healthcare research. As such, it makes a contribution to the recently called for 'sociology of biobanking' (Lipworth et al, 2011). Key to this article is my embedding of this theoretical account within the empirical realities of onCore UK and the UK Stem Cell Bank. 


\section{Institutional Imaginaries of Cancer and hESC Tissue Banking}

Both banks arose from the same regulatory context and started at similar times, the UK Stem Cell Bank established in 2002, opening in 2004; and onCore UK established in 2005, opening in 2006, and ceasing biobanking activity in 2009. Both acted as repositories situated between patient-donors and scientists intended to supply laboratory-ready tissue for therapeutic-oriented research programmes. Furthermore, both operated on a similar scale with 8-14 staff and many broader associated networks. They also both planned to operate as hubs for their research areas, distributing both tissue and standardised best practice. Neither charged researchers for accessing the material, unlike other banks in the sector, although both had provisions for requesting accessing laboratories to cover the direct costs of transportation. However, there are also clear differences between the banks related to the differing contexts of hESCs and cancer tissue as historically located socio-technical artefacts.

There are key differences in each bank's imaginary that relate to the ontological, temporal and ethical specifics of the tissue they hold. onCore UK stored material from patient-donors that was associated with illness: a process of decline and morbidity (Adam, 2004). It was diseased tissue used to study disease, a model of the human body gone wrong, which was to be understood and possibly returned to a healthy state. The UK Stem Cell Bank is quite different. It holds tissues associated with health: a process of growth and vitality (Adam, 2004). It is the imagined biological potential of hESCs to cure disease that is valued and preserved. While onCore UK operated within an established paradigm of addressing disease, the UK Stem Cell Bank works within the now wellemerged world of regenerative medicine. This is a broader, more ambitious imaginary where the potential disease categories targeted extend as broadly as knee cartilage damage to Parkinson disease. ${ }^{4}$ Furthermore, hESCs promise opportunities beyond therapy into the realms of enhancement, not just 'returning the body to its original state' after accident or illness, but also 'improving upon normalness'. Essentially, there are different forms of time frame (Adam, 2004) embedded within these imaginaries ascribing the tissues held with different ontological value based on their location within differently understood notions of biological process and futures. These are differences of the present, but also differences of how far the assumed productivity of the tissues reaches into the future.

A further difference between the banks relates to the ethical contention of the material. hESC lines are embedded within familiar controversies around the primacy of the embryo and the exploitation of women donors (Holland et al, 2001; Holm, 2002). Following this, the UK Stem Cell Bank imaginary takes as central the demonstration of ethical legitimacy. The containment, or satisfaction, 
of public concern and distrust is foundational to the work of the UK Stem Cell Bank specifically and UK stem cell science regulation more broadly. This is not to say that onCore UK was free of ethical consideration. Operating in the wake of the organ retention scandals, all tissue-holding institutions in the United Kingdom must demonstrate proper procedures. For onCore UK, like the UK Stem Cell Bank, this meant detailed scrutiny of informed consent procedures. However, in onCore UK's case, the controversy was over ensuring the correct passage of material into the bank, and not the ontological nature of the material itself.

\section{Funding and Institutional Context}

The two banks originate in overlapping but different institutional settings. onCore UK was established in 2005 as the National Cancer Tissue Resource, and was later renamed onCore UK. It was funded by the main funders of cancer research in the United Kingdom - the Department of Health (50 per cent), Cancer Research UK ( 25 per cent) and the Medical Research Council ( 25 per cent). onCore UK was a charitable company limited by guarantee and managed by a Board of Trustees. As such, it was an interesting hybrid institutional form, working as a not-for-profit charity neither aligned with the university sector nor developed by patient representative groups. ${ }^{5}$

The UK Stem Cell Bank was first suggested in a Department of Health report and later deemed essential in a House of Lords report advocating that the primary research funding bodies in the area - the MRC (50 per cent) and the BBSRC (50 per cent) - supply generous financial support. It was the first stem cell bank of its kind in the world, and continues to be the leader of an emergent group of around seven others (Stephens et al, 2011a). Indeed, the importance of the bank as performative of the United Kingdom's cutting-edge bioscience sector is a clear justification for the expenditure in the House of Lords (2002) report. This innovative capacity reveals another clear difference between the banks. While the UK Stem Cell Bank is the first and only one of its type in the United Kingdom, onCore UK was one of a network - the Confederation of Cancer Biobanks - that have similar objectives and methods. After having its remit changed, onCore UK functioned as the secretariat to the confederation.

Although both banks have commonalities in their funders, there are important differences that both reflect and are performative of their institutional trajectories and the timelines they embody. onCore UK was initially funded for 5 years with MRC and Department of Health seedcorn money, with no guarantees of continuation at a similar level. This 5-year period expired in 2009 and was not extended, causing the cessation of biobanking activity. onCore UK staff 
were aware of this possibility and worked hard to try and prevent it. After this, for more than a year, onCore UK continued to be funded by an under-spend from the previous grant and sought subsequent funding to continue its advisory work after this money was spent. However, they were unsuccessful, and in February 2011 onCore UK ceased to exist. The UK Stem Cell Bank was also originally funded on a 5-year basis and came up for review in 2007. Although keen to demonstrate their professionalism and good work, the UK Stem Cell Bank did not fear losing funding in the same way and received a time extension (Adam, 2004), fully funding it for another 5 years. In 2011, the bank's funding was further extended until 2014.

\section{Banks as Spaces and Places}

Institutions appropriate spaces and places, the conceptual and the physical. As information, people and material flow through these spaces and places, symbolic and practical work is accomplished. onCore UK and the UK Stem Cell Bank are no different in this respect. The specifics of their spatial organisation reflect important aspects of their institutional imaginaries. I start by discussing the spatial organisation of the banks and how it relates to each bank's performance of legitimate behaviour, operating to satisfy an imagined set of publics and the tacit knowledge ways they use to make trust judgements about scientific institutions (Jasanoff, 2005).

The UK Stem Cell Bank has a Steering Committee: an ethical oversight group that pass judgement on what material comes into the bank and what material leaves. Committee members have a broad range of backgrounds, demonstrating a form of democratic accountability in their decisions (Stephens et al, 2008b). Perhaps more pertinent here is how the bank uses spatial and physical distance to demonstrate legitimate practice. This legitimacy is founded on eradicating potential conflict of interest scenarios in the bank's decision making. It is a clear example of Gieryn's (1999) boundary work, and such practices are common throughout the bank's work and UK stem cell regulation more broadly (Salter and Salter, 2007). The people who make decisions on the Steering Committee are not the people who work on the physical aspects of stem cell banking. The laboratory workers of the UK Stem Cell Bank are not permitted to conduct research into stem cell biology, as to do so would dangerously place them in competition with the research institutions they serve. Equally, the bank is not allowed to derive hESCs, that is, destroy human embryos in the laboratory to produce stem cell lines, as again, this would be a conflict of interest. The bank is funded essentially from government money, but via intermediary organisations - the MRC and BBSRC - that are intended to place a buffer between science 
spending decisions from the realm of government. As Jasanoff argues, this is of course a culturally specific register of legitimate action rooted in the specifics of UK history. ${ }^{6}$

onCore UK followed similar principles, but, as described earlier in reference to their leading imaginary, the ontological nature of the material was not politically controversial in the way hESCs are. Therefore, their performance of legitimacy took on a different form. However, they still had a Board of Trustees and an independent Ethics and Standards Advisory Panel that counted among their members funding bodies, bioethicists, scientists and representatives of disease groups. These groups made decisions affecting the operation of the bank, in the Board of Trustees case to the extent of being able to reconfigure its role and shut it down. The committee structures in both banks, spreading decision-making processes across different, hierarchical, spaces, make the banks' layered institutions engaged in the moral work of guardianship as tissue passes through their circuits of exchange. This boundary work involves boundary maintenance not only between the banks and other institutions, but also within and across their own institutional spaces. It is for these reasons that co-authors and I have elsewhere used the term 'moral refineries' to describe these activities, the layered disentangling and re-entangling of contentious tissue into formalised patterns of exchange (Stephens et al, 2008a).

But let us turn to the physicality of place. Elsewhere, co-authors and I have developed Thrift's (2006) concept of 'performative architecture' to explicate how the walls, doorways, pathways and junctions of the UK Stem Cell Bank laboratory both perform and problematise metaphorical visions of sterile practice (Stephens et al, 2008a). Here I use the concept in a very different way, more in keeping with Thrift's original specification of its meaning. He used the concept in relation to buildings such as the Centre for Life at the University of Newcastle and the Wellcome Trust Biocentre at the University of Dundee to explicate how the architectural structuring of these purpose-built buildings enacts their role as 'innovation incubators' (p. 292), as 'gleaming temples to interdisciplinary bioscience' (p. 292). Thrift identifies five features common to these buildings that facilitate this performance: their interdisciplinary mixing of office and lab space; their porous through-flows of information and personnel; their creative sociability in a buzz-generating café culture; their physical transparency; and the frequently explicit representation of 'life' in their structuring. ${ }^{7}$ We can add to this spatial characterisation the key temporal features that facilitate these actions: they coincide working time patterns aligning the rhythmicity of multiple disciplines; they promote instances of exchange in shared work time in offices and shared downtime in their creative cafes; and they allow the formation of shared future visions and communal processes. 
The UK Stem Cell Bank is housed at the National Institute of Biological Standards and Control (NIBSC) near Potters Bar, north of London. NIBSC has a tradition of over 20 years as a leading international body in setting standards for biological reference materials and producing tests for challenges such as Creutzfeldt-Jakob Disease and pandemic influenza. This co-location is not by chance, as the association merited strong support in the bidding competition to house the bank. While supporting the work of the bank, it also lends credence to its aspirations as a pioneer in setting standards in stem cell research. Furthermore, NIBSC is not a potential user community for the bank's stem cell stock. Locating the bank at a university would have threatened the boundary work inherent in the denial of conflict of interest detailed above.

Unlike Thrift's examples, the bank has not been, externally at least, an ostentatious building. For the first 5 years of its existence, the bank was housed in a small temporary building - often described as a porta-cabin - attached to the back of the NIBSC building. It housed a small number of the bank's staff and three sophisticated laboratories. A larger two-storey permanent building for the bank on the same site opened in 2010. The symbolic reading of the 'temporary building' by those associated with the bank is interesting. It is never interpreted as a sign of the bank's potential transience or lack of future-orientated vision, nor allowed to invoke a limited timescale or locate the bank as insufficiently robust or lacking time extension (Adam, 2004). Instead, it is proudly presented as a symbol of the bank's world-leading status and efficient organisation through reference to the speed with which a temporary building can be made operable in comparison with a permanent build (Stacey, 2004). In Adam's terms, it was presented as a success of tempo and the pace with which they were able to move, a specific construction of temporality that deemed their practices legitimate. Any interpretation of transience is challenged initially by reference to architects plans and latterly to a building site becoming a building. This draws temporality and spatiality together. As Gieryn (2002) argues, the physicality of the building conveys permanence and belies the temporal realities of its funding structure. The bringing into being of the space brings into being an important part of the bank's imaginary: the stability of space performs the stability of the still controversial biotechnology it contains. By materialising the place, the bank, in part, materialises the technology.

This stands in marked contrast to onCore UK, which during its biobanking phase existed in a hired office space in a business unit where its eight direct employees were all based. From this site, a broad set of virtual and distanced forms of control and organisation were initiated and monitored. Samples were collected by the Biosample Donation Networks or extracted from historical archives that are located in various NHS trusts across the United Kingdom. They were then transported and stored in a rented cryopreservation facility, a large 
warehouse of biological samples from a wide range of biological institutions, run by the US Thermo Fisher Corporation near Stanstead airport. Computer technicians in the hired office space annotated the material, re-constituting the biosamples within an exchangeable culture of documented rationality, which was then stored remotely at a commercial data storage company. The people in the office had little contact with the rented biological or computer space: short-term staff were taken on to work in the storage space. This is highly transient in practice. The paradox is that, although recognised as a Biobank, the onCore UK central space and the people who worked there had little or no contact with the material at the point of collection, storage or planned distribution. It operated as a central site of coordination and mediation, a distributed moral refinery.

This brings a very different meaning to the idea of performative architecture. The work above and in my paper on the production of metaphorical visions of sterility (Stephens et al, 2008a) follow Thrift's form of reasoning: I discuss what the physical architecture performs, the symbolic, moral and practical work that the building produces. This stands in contrast to the meaning I bring to the term in the case of onCore UK. Here the architecture - the physicality of place - was performed and maintained in the absence of place. onCore UK existed as the social alignment of disparate forms, practices and people. It was denied the opportunity to materialise the imaginary in which it operated through the traditional forms of architecture enjoyed by the UK Stem Cell Bank. The successful operation of onCore UK involved the denial of its transience through stabilising networks, not places. I come to what these networks were in the following sections.

\section{Tissue and Temporality}

There were two routes for human tissue into onCore UK's repository, each with quite different temporal trajectories. The first - via Biosample Donation Networks - was a constituent element of onCore UK's imaginary, engaging with cancer sufferers as they undergo NHS treatment to allow the donation of material. The second was unanticipated, and involved the large-scale incorporation of archived human tissue used previously for diagnostic purposes in hospitals. The first and only instance of this was the transition of 40000 tissue samples taken in the 1930s-1970s by a northern English NHS trust and subsequently warehoused and largely untouched until late 2008, when the material passed on to onCore UK. In this respect, the bank is a shared temporal junction for multiple trajectories through the intersection of treatment and research in the cancer biobanking tissue economy. These two routes for material into the 
bank represent quite different forms of 'gift relationship' (Titmuss, 1970; Tutton, 2002) ${ }^{8}$ and related timescape. The Biosample Donation Networks were designed and facilitated by onCore UK to be an intermediary between living patients (with living, but diseased, tissue) and the bank. They exist to disentangle the tissue from networks of suffering, diagnostics and healthcare and re-entangle it into documented, exchangeable form in the tissue economy. This is tissue of the present, the time point of collection (Adam, 2004), moved directly into the opening layers of the biobank.

In pursuit of the first of these trajectories, onCore UK developed strategic allegiances with a number of NHS trusts to collect the tissue donations. In 2006, all National Health Service Clinical Trial Networks that were part of the National Cancer Research Network were invited to submit bids to work with onCore UK. From the bids submitted, an independent review committee selected the initial onCore UK Biosample Donation Networks that would become the first point of engagement for patient-donors within onCore UK's distributed moral refinery. Each agreed on targets and procedures for biosample collection, and onCore UK provided funding and training for the local practitioners to start collecting samples. ${ }^{9}$ They collected blood and tumour samples from any cancer patient willing, provided it did not impact on their clinical care. Specifically trained healthcare professionals, based at the NHS trust hospitals, used onCore UK's ethically accredited consent documents to guide the informed consent process. ${ }^{10}$

The second trajectory - the incorporation of historical NHS tissue archives involved a very different type of temporal complexity, with tissue collected from the patient at a very distant time point (Adam, 2004). This material did not come from living patients. It was also largely unsorted and badly maintained, often kept in dusty warehouses left forgotten. The initial late 2008 deposit occurred because the NHS trust holding the material opted to demolish the unwanted building and saw no need to hold onto the tissue inside. onCore UK provided a future for this precariously transient material, but a future based in a very different imaginary to that for which it was originally collected. The material was archived for the direct medical benefit of the patient, never constructed as a patient-donor. The tissue was a diagnostic resource for evaluating their health trajectory with no intended utility beyond that individual. Re-entangling this within networks of donorhood and exchange is a strong move that, on some levels, challenges onCore UK's model of public and ethical accountability. There is no informed consent for research on this tissue and none can be sought as the donors passed away many decades ago. It also positions the tissue in a different time frame, with utility in the future as opposed to the past.

hESC lines also have complex temporalities, but in quite different ways. As Waldby (2002), Brown and Webster (2004) and Franklin (2005) describe, the 
growth potential of stem cells challenges our conception of the linearity of life. These authors point to the potential to reconfigure what Adam $(1998,2004)$ refers to as time sequence, reordering biological series and pausing growth at a single time point. hESCs are derived during the destruction of an embryo, subverting the biological vitality that could lead to the growth of a human being and instead containing it, storing it - for example, in the UK Stem Cell Bank and then moulding it towards therapeutic ends by encouraging the material to differentiate into other more developed types of human material. This harnessing and re-ordering of the growth potential of stem cells lies at the heart of the regenerative medicine promise to improve healthcare.

The tissue at the bank has overwhelmingly come from laboratories in the United Kingdom and around the world that in turn obtain embryos from IVF clinics, which in turn obtain gametes from women looking to undergo IVF treatment (Waldby, 2002; Franklin, 2006). These are socially complex spaces where disentanglement and re-entanglement occur, shifting the material from patient-centred networks of kinship and ethical contention to research-focused networks of correct moral guardianship and exchangeable forms (Waldby and Mitchell, 2006; Ehrich et al, 2010). This process includes transition periods through IVF clinics, laboratories, the UK Stem Cell Bank Steering Committee and the UK Stem Cell Bank laboratory space itself. This staged and staggered inward journey gives rise to the conception of the bank as a moral refinery: an institution that produces moral legitimacy through its layered geography. While we can term the space a moral refinery, the process of movement through this space, and across time, is one of moral refining, a property of temporality that is hard to grasp in action, although the start and end points may be visible (Adam, 1990, 2004). Moral refining accredits the technical and social value of tissue as it passes through the refinery, taming the socially complex temporalities and controlling its historicism.

The differences between the two banks are less pronounced once the tissue enters their space. Tissue collections should not be transitory; the role of a bank as archive or repository invites an interpretation of permanence. It involves the muting of the tissues' complex temporal trajectories and their incorporation into controlled models of exchange, ripe for circulation through the tissue economy. As well as the boundary work of onCore UK's Ethics and Standards Advisory Panel and the UK Stem Cell Bank's Steering Committee, both Banks engage in detailed documentary practices for the material, extracting an existence for the tissue beyond its physical biological boundary, and opening it to movement and storage within spaces of bureaucratic accountability (Stephens et al, forthcoming). Elsewhere, I have detailed some of the problems of translating these embodied and tacit understandings into a disembodied exchangeable form in relation to the UK Stem Cell Bank (Stephens et al, 2011b). 
I describe how highly specific details of the hESC lines derivation conditions are recorded in the Cell Line Information Form aligning the tissue with the international standards of Good Manufacturing Practice that accredit its circulation for transplant into patients.

At onCore UK, each sample location was registered on 'CELL', a Biosample Information Management System developed specifically for this purpose. If onCore UK had progressed far enough to make anonymised samples available to researchers, the CELL system would have linked to onCore UK's distribution portal, the Biosample Expeditor Service, allowing researchers to obtain clinical information about the samples. onCore UK worked to integrate specific data from cancer registries local to their partner hospitals and from the developing National Cancer Intelligence Network. These processes of structuring the samples in a disembodied textual form are central to the entanglement of both patient-donor and archive-sourced tissue into a new exchangeable form. The recording of the donation's form and location makes onCore UK's claim to hold the material meaningful. It bestows credibility, authority and ownership. It exemplifies the 'audit culture' of contemporary organisational work (Strathern, 2000; Lewis and Atkinson, 2011). The symbolic importance of this was instantiated in the practical organisation of the bank in the employment of an equal number of computer technicians to develop and implement data recording systems, as there were staff involved in the hands-on biological work of storage. In both banks, these bureaucratic processes - CELL and the Cell Line Information Form - control and harness the complex temporality of the tissues held. They make the donated material universal and control its historicism.

Despite these similarities, there are significant differences between the flows of material out of the bank's space that centre on the varied temporality of the tissue types. At the simplest level, the UK Stem Cell Bank started actively distributing material in 2006, whereas the majority of the distribution of material at onCore UK was to return the stock to the hospitals that collected it after they ceased biobanking activity. Although this relates to the funding decisions made about the banks, there remain other issues worthy of consideration comparing the hESC and cancer tissue. The UK Stem Cell Bank can proliferate the material it holds. This means that very little donated material can result in large quantities of tissue available for research. A single deposit can result in almost endless accessions as the proliferation potential of the hESC material is harnessed. For onCore UK, and other existing cancer Biobanks, this dynamic could never exist. They operate in terms of single units, and one donation can only ever result in a small finite number of accessions. Furthermore, as material exits onCore UK, their stock depletes, meaning new tissue needs to flow into the bank to maintain its imaginary. This is not necessarily the case with the UK Stem Cell Bank, as successive accessions require continued in-house proliferation 
of their existing holdings. A continued stream of material flowing inwards is not a necessary element of their operation. They are less reliant than cancer biobanks on stabilising the networks that maintain the flows of material into their repository. The material itself need not be transient as it flows in and out of the UK Stem Cell Bank as is required in cancer biobanking. ${ }^{11}$

\section{Discussion}

This article has presented a comparison of two banks: one that holds stem cell lines and one that held cancer tissues; one with a centralised physical space and one with a more distributed form. But the reader will be keenly aware that it is also a comparison of one bank that has been successful and another that ceased biobanking activity. This discussion addresses the research question stated in the introduction: in these two empirical studies how do spatial and temporal aspects challenge and help materialise each bank's institutional imaginary, while also developing a tentative narrative around how these issues relate to biobank closure?

This article has made explicit the institutional imaginaries of both banks. Both have aimed to provide ethically assured and technically well-documented tissue for researchers. However, these imaginaries can be differentiated by ontological judgements about the temporality and potential of the two tissue types. While cancer tissue is entangled with networks of disease and progression through illness, hESC lines are entangled within networks of health, growth and biological improvement. Constitutive of these ontological judgements are further judgements about the moral value of their methods of sourcing. Although both operated in a political context where the storage of human tissue requires inspection and robust guardianship, the ethical status of hESC lines provoked greater levels of bureaucracy and performance of legitimate practice owing to the inherent destruction of human embryos.

I have described how boundary work is central in both case studies to the performance of legitimate practice, both in conceptual organisational terms through committee structures and external review, and in physical terms through the building and performance of structures and locations. These complex constellations of layered physical and organisational boundaries within the institutions themselves are the basis for describing them as moral refineries, active in moral refining, making material institutional imaginaries around legitimacy. The movement of tissue through the banks disentangles it from the complex temporal and ontological networks in which it was sourced, and instead re-entangles it within networks of bureaucratic accountability and exchange within the tissue economy. 
In the case of the UK Stem Cell Bank, the complex ontology and temporality of the tissue relates to the destruction of the embryo and the pausing and control of its biological vitality, re-orientating it from a potential for developing into a human being to a potential for developing therapeutic products and techniques. This is central to the regenerative medicine imaginary. In the case of onCore UK, the ontological and temporal complexity differed with the two different sources of its holdings. Material taken directly from patient-donors via Biosample Donation Networks underwent immediate re-entangling from networks of patient care to networks of tissue exchange as the bank's layered form extended directly to the moment of tissue collection. In contrast, the NHS archive material was collected from the patient at a distant time point within an imaginary of individualised patient care. Here, onCore UK engaged in the sociotechnical work of re-entangling the material within a different imaginary and different institutional context. In all three instances, the work of each bank as a moral refinery is to control this temporal and ontological complexity, providing tissue suitable for distribution.

I have stressed the opportunities and challenges related to the physicality of buildings in materialising each bank's imaginary. As Gieryn notes, '[b]uildings stabalize social life. They give structure to social institutions, durability to social networks, persistence to behaviour patterns. What we build solidifies society against time and its incessant forces for change' (Gieryn, 2002, p. 35). However, he also warns that '(s)ociologists should take buildings more seriously, but maybe not too seriously. The play of agency and structure happens as we build: we mold buildings, they mold us, we mold them anew .... In buildings, and through them, sociologists can find social structures in the process of becoming' (Gieryn, 2002, p. 65). The case studies reported here provide further evidence of the nuanced and contingent form the relationships between buildings and the social structures in and around them take. In the UK Stem Cell Bank example, it is clear that the discursive work of the staff at the bank acted to close down the interpretative flexibility of their porta-cabin physical structure. Instead of being symbolic of the transience of their funding structure, or raising questions over the institution's longevity, their temporary structure was deemed symbolic of their ability to move quickly and establish robust mechanisms in a short time frame. Here constructions of tempo materialise stability even when this could be challenged by the physical form of the building.

The solidifying strength of buildings is evident at the UK Stem Cell Bank, where the continued investment in building a two-storey permanent structure to replace the original temporary building was greeted with a public celebration at its official opening in late 2010. The bank's aspiration to operate in collaborative networks is now instantiated through their 'hotel' laboratory that provides visitors with a work space of their own (National Institute for Biological 
Standards and Control, 2010). While the architecture is performative of this set of assumed social relations around a stem cell community spurred on by shared biological material, shared scientific understandings and shared scientific spaces, Gieryn's empirical work directs us to recognise the potential interpretative flexibility of these spaces as they can be moulded and used in alternative ways.

I have described onCore UK as a distributed moral refinery, reflecting the geographical spread of its operations and the labour required by its staff to stabilise networks against the challenge of the absence of permanent space. Whether distributed or not, in both cases the spatial layering of each institution's physical and organisational structures and their systems of bureaucratic accountability works to accredit the socio-technical value of the tissue passing through them. Through processes of disentangling and re-entangling the symbolic alignments of human biological material, the institutions tamed their complex temporalities and ontologies that become inherent in their work as mediators between patient-donors and biomedical researchers. It is clear that temporal and spatial aspects inherently frame the processes of materialising each bank's institutional imaginary.

I do not wish to claim that the differences discussed in the article are directly responsible for the differing levels of success experienced by each bank. Considerations about budgets, productivity and competitor organisations are also important explanatory elements in onCore UK's cessation of biobanking activity. However, the different levels of success experienced by the banks do invite a tentative reflection on the issues raised in the article and the divergent outcome experienced by each.

It can be argued that the ontological nature of the hESC line, as the politically controversial product of the destruction of a human embryo, would be perceived in the United Kingdom as having a greater need for sustained moral refining. In the absence of any other institution able to offer moral guardianship of this tissue, the UK Stem Cell Bank's stability is premised on the perceived need for a stable resolution to the moral questions its biological stock raises. This is not the case for onCore UK, where numerous other cancer biobanks exist and the cause for ethical sensitivity lies with the informed consent of the patient-donors, but not the ontological questions over the existence of the material itself. Unlike onCore UK, the closure of the UK Stem Cell Bank would have significant impact on the legitimacy of UK hESC science.

But buildings are also representative of broader social relationships, not least economic, and the construction of a built facility was never on onCore UK's agenda. There was no support for such a facility among the institutions that devised and funded the bank.

The tissue at both banks has complex temporalities bound by its ontological status and ethical framing. By disentangling it from its pre-banking associations 
and re-entangling it within networks of auditable accountability, correct ethical guardianship and quality assured physical form, both banks act to produce human biological material for exchange. The concept of the bank invites the interpretation of permanence, taming, controlling or denying the material's complex historicism. Yet we can see in both cases - the UK Stem Cell Bank and onCore UK - that these institutional forms are themselves complex, with timelimited funding structures, social networks and physical spaces. These banks, like buildings, attempt to stabilise social life, giving structure, durability and persistence to the storage and exchange of human tissue. But also like buildings, the broader social structures they seek to constrain can also frame, and in onCore UK's case undermine, the stability of the banks themselves. Both in theoretical and practical terms, it is worth remembering that although banks may invite an interpretation of permanence, it is not necessarily the case that this permanence will be delivered.

\section{About the Author}

Dr Neil Stephens is a Cesagen Research Fellow at the ESRC Centre for the Economic and Social Aspects of Genomics (Cesagen), Cardiff University School of Social Sciences. His research interests are stem cell science, cancer treatment, in vitro meat and the Afro-Brazilian dance/game/martial art Capoeira.

\section{Notes}

1 The article reports the work of three wider projects, all funded by the Economic and Social Research Council (ESRC) - 'Curating and Husbandry in the UK Stem Cell Bank' (Project No. Res-00022-1136; 1 March 2005-28 February 2006), 'The UK Stem Cell Bank - An Institutional Ecology' (Project No. Res-349-25-0001; 1 March 2006-28 February 2009) and the ESRC Cesagen Research Development grant 'onCore UK in context' (1 November 2008). The support of the ESRC is gratefully acknowledged. This work is part of the Research Programme of the ESRC Genomics Network at Cesagen (ESRC Centre for Economic and Social Aspects of Genomics).

I also thank Barbara Adam, Chris Groves, the Cesagen journal club, the editors and two anonymous referees for their valuable comments.

2 The UK Stem Cell Bank is also mandated to hold adult and foetal stem cell lines, although the vast majority of its collection remains hESC lines. It does not hold cord blood.

3 UK Stem Cell Bank data collection, interviews $n=36$. onCore UK data collection, interviews $n=14$.

4 Some even see stem cell science as a practical tool for tackling climate change and animal welfare issues though the production of laboratory-grown meat for human consumption (Stephens, 2010).

5 This has some commonality with the organisational form suggested by Dixon-woods et al (2008). 
6 Legitimate practice is performed quite differently at the Spanish Stem Cell Bank (Stephens et al, 2011a).

7 I would add to his articulation by arguing that the Newcastle Centre for Life has further performitivity beyond this model of innovation, as a publicly accessible space of 'legitimate' and 'acceptable' science. As well as cutting-edge laboratories, the Centre also houses exhibitions and lectures, allowing school groups and families to participate in the futuristic space of modern science, and to be educated and reassured. The Centre for Life at Newcastle is an important space in the history of the UK Stem Cell Bank, as it was here that one of the first hESC line donations to the bank was both donated and derived, depending on the co-location of both the IVF clinic and stem cell science laboratories. But such innovative spaces are not limited to the United Kingdom. Perhaps the most striking example is the Biopolis in Singapore, a US $\$ 290$ million, 18.5 hectare and seven-building site of interlinking skybridges (Smaglik, 2003) containing centres for bio-tech disciplines including bio-informatics, genomics and cell biology, which could feature a stem cell bank of its own.

8 The 'gift relationship' was articulated by Titmuss to describe the altruistic donation of blood as an act of social cohesion. The appropriateness of Tutmuss' terminology has been questioned in a contemporary context by Waldby and Mitchell (2006) and empirically explored in the case by childhood cancer tissue donation by Dixon-woods et al (2008).

9 The eventual inability of the Biosample Donation Networks to deliver these stated quantities proved a contributing factor in the decision to eventually cease biobanking activity.

10 See Jackson et al (2009) on the motivations and concerns of health professionals taking consent for tissue banking in the childhood cancer field.

11 Despite this, the flows of material into the UK Stem Cell Bank are stable and backed by law, as any hESC line derived in the United Kingdom must, as part of the Human Fertilisation and Embryology Authority licence that allowed its production, be deposited in the bank.

\section{References}

Adam, B. (1990) Time and Social Theory. Cambridge, UK: Cambridge University Press.

Adam, B. (1998) Timescapes of Modernity: Environment and Invisible Hazards. London: Routledge. Adam, B. (2004) Time. Cambridge, UK: Polity Press.

Brown, N. and Webster, A. (2004) New Medical Technologies and Society: Reordering Life. Cambridge, UK: Polity Press.

Callon, M. (ed.) (1998) Introduction: The embeddedness of economic markets in economics. In: The Laws of the Markets. Oxford: Blackwell, pp. 1-57.

Dixon-woods, M. et al (2008) Tissue samples as 'gifts' for research: A qualitative study of families and professionals. Medical Law International 9(2): 131-150.

Ehrich, K., Williams, C. and Farsides, B. (2010) Fresh or frozen? Classifying 'spare' embryos for donation to human embryonic stem cell research. Social Science \& Medicine 71(12): 2204-2211.

Eriksson, L., Stephens, N. and Webster, A. (2008) Stem cell spaces, places and flows. New Genetics and Society 27(2): 83-87.

Franklin, S. (2005) Stem cells R US: Emergent life forms and the global biological. In: A. Ong and S. Collier (eds.) Global Assemblages. Blackwell: Oxford, pp. 59-78.

Franklin, S. (2006) The cyborg embryo: Our path to transbiology. Theory, Culture \& Society 23(7-8): $167-188$.

Gieryn, T. (1999) Cultural Boundaries of Science. London: University of Chicago Press.

Gieryn, T. (2002) What buildings do. Theory and Society 31(1): 35-74. 
Gray, R. (2010) Drug and cosmetics firms back plan to cut animal testing. The Telegraph. 27th November, http://www.telegraph.co.uk/science/science-news/8165125/Drug-and-cosmeticsfirms-back-plan-to-cut-animal-testing.html, accessed 8 December 2010.

Gross, C. (2004) Struggling with imaginaries of trauma and trust: The refugee experience in Switzerland. Culture Medicine and Psychiatry 28(2): 151-167.

Harrington, J. and Stephens, N. (2010) A social science view on the FRAME symposium: Identities and networks. Alternatives to Laboratory Animals 38(supplement 1): 101-104.

Holland, S., Lebacqz, K. and Zoloth, L. (2001) The Human Embryonic Stem Cell Debate. Cambridge, MA: MIT Press.

Holm, S. (2002) Going to the roots of the stem cell controversy. Bioethics 16(6): 493-507.

House of Lords (Stem Cell Research Select Committee). (2002) Stem Cell Research: Report From the Select Committee. London: The Stationery Office Limited.

Jackson, C., Dixon-woods, M., Tobin, M., Young, B., Heney, D. and Pritchard-jones, K. (2009) Seeking consent to tissue banking: A survey of health professionals in childhood cancer. European Journal of Cancer Care 18(4): 391-400.

Jasanoff, S. (2005) Designs on Nature. Woodstock, UK: Princeton University Press.

Jasanoff, S. and Kim, S. (2009) Containing the atom: Sociotechnical imaginaries and nuclear power in the United States and South Korea. Minerva 47(2): 119-146.

Kelty, C. (2005) Geeks, social imaginaries, and recursive publics. Cultural Anthropology 20(2): $185-214$.

Lewis, J. and Atkinson, P. (2011) The surveillance of cellular scientists' practice. BioSocieties 6(4): $381-400$.

Lipworth, W., Forsyth, R. and Kerridge, I. (2011) Tissue donation to biobanks: A review of sociological studies. Sociology of Health \& Illness 33(5): 792-811.

National Institute for Biological Standards and Control. (2010) UK Stem Cell Bank Progress Report Phase II 2006-2010. Potters Bar, UK: National Institute for Biological Standards and Control.

Pickersgill, M. (2011) Connecting neuroscience and law: Anticipatory discourse and the role of sociotechnical imaginaries. New Genetics and Society 30(1): 27-40.

Rommetveit, K. (2011) Genetic enhancement, future tense. Futures 43(1): 76-85.

Salter, B. and Salter, C. (2007) Bioethics and the global moral economy: The cultural politics of human embryonic stem cell science. Science Technology and Human Values 32(5): 554-581.

Smaglik, P. (2003) Singapore: filling biopolis. Nature 425(6959): 746-747.

Stacey, G. (2004) First Report From the UK Stem Cell Bank. Potters Bar, UK: National Institute for Biological Standards and Control.

Stephens, N. (2010) In vitro meat: Zombies on the menu? SCRITPed: A Journal of Law, Technology \& Society 7(2): 394-401.

Stephens, N., Atkinson, P. and Glasner, P. (2008a) The UK stem cell bank as performative architecture. New Genetics and Society 27(2): 87-99.

Stephens, N., Atkinson, P. and Glasner, P. (2008b) The UK stem cell bank: Securing the past, validating the present, protecting the future. Science as Culture 17(1): 43-56.

Stephens, N., Atkinson, P. and Glasner, P. (2011a) Internationaliser des standards, metter en banquet avec confiance: La mise en banquet de cellules souches $\mathrm{S}$ trois systèmes nationaux. Revue D'anthropologie des Connaissances 2(5): 260-286.

Stephens, N., Atkinson, P. and Glasner, P. (2011b) Documenting the doable and doing the documented: Bridging strategies at the UK stem cell bank. Social Studies of Science 41(6): 791-813.

Stephens, N., Lewis, J. and Atkinson, P. (forthcoming) Closing the regulatory regress: GMP accreditation in stem cell laboratories. Sociology of Health \& Illness.

Strathern, M. (2000) Audit Cultures: Anthropological Studies in Accountability, Ethics and the Academy. London: Routledge.

Taylor, C. (2004) Modern Social Imaginaries. Durham, N.C. and London: Duke University Press. 
Thrift, N. (2006) Re-inventing invention: New tendencies in capitalist commodification. Economy and Society 35(2): 279-306.

Titmuss, R. (1970) The Gift Relationship. London: Allen and Unwin.

Tutton, R. (2002) Gift relationships' in genetics research. Science as Culture 11(4): 523-542.

Tutton, R. (2007) Banking expectations: The promises and problems of biobanks. Personalised Medicine 4(4): 463-469.

Waldby, C. (2002) Stem cells, tissue cultures and the production of biovalue. Health 6(3): 305-323.

Waldby, C. and Mitchell, R. (2006) Tissue Economies: Blood, Organs, and Cell Lines in Late Capitalism. London: Duke University Press. 